http://dx.doi.org/10.1590/1678-4162-7421

Arq. Bras. Med. Vet. Zootec., v.67, n.5, p.1231-1240, 2015

\title{
Cardiopulmonary parameters in propofol- or thiopental-anesthetized dogs induced to pulmonary hypertension by serotonin
}

\author{
[Parâmetros cardiopulmonares em cães anestesiados com propofol ou tiopental e induzidos à \\ hipertensão pulmonar pela serotonina] \\ P.C. Ferro Lopes ${ }^{1}$, N. Nunes ${ }^{2}$, D.P. Paula ${ }^{1}$, C.T.D. Nishimori ${ }^{1}$, J.V. Moro ${ }^{1}$, \\ E.D.V. Conceição ${ }^{1}$, P.S.P. Santos ${ }^{3}$ \\ ${ }^{1}$ Aluna de pós-graduação - Faculdade de Ciências Agrárias e Veterinárias - FCAV-Unesp - Jaboticabal, SP \\ ${ }^{2}$ Faculdade de Ciências Agrárias e Veterinárias - FCAV-Unesp - Jaboticabal, SP \\ ${ }^{3}$ Faculdade de Medicina Veterinária de Araçatuba - FMVA-Unesp - Araçatuba, SP
}

\begin{abstract}
The cardiopulmonary changes in propofol- or thiopental-anesthetized dogs induced to pulmonary hypertension $(\mathrm{PH})$ were evaluated. Twenty adult animals were randomly assigned to two groups: propofol group (PG) and thiopental group (TG). In PG, propofol was used for induction $\left(8 \pm 0.03 \mathrm{mg} \mathrm{kg}^{-1}\right)$ and anesthesia maintenance $\left(0.8 \mathrm{mg} \mathrm{kg}^{-1}\right.$ minute $\left.{ }^{-1}\right)$, while, in TG, thiopental was used $\left(22 \pm 2.92 \mathrm{mg} \mathrm{kg}^{-1}\right.$; $0.5 \mathrm{mg} \mathrm{kg}^{-1}$ minute $^{-1}$, respectively). Mechanical ventilation using time cycle was started. $\mathrm{PH}$ was induced by administration of serotonin (5HT) $\left(10 \mu \mathrm{g} \mathrm{kg}^{-1}\right.$ and $1 \mathrm{mg} \mathrm{kg}^{-1}$ hour $\left.{ }^{-1}\right)$ through a thermodilution catheter positioned in the pulmonary artery. The measurements were performed before administration of 5HT (T0), after 30 minutes (T30), then at 15-minute intervals (T45, T60, T75 and T90). No differences between groups were registered for systolic (sPAP) and mean pulmonary arterial pressure (mPAP), mean arterial pressure (MAP), total peripheral resistance index (TPRI) and pulmonary vascular resistance index (PVRI). In PG, sPAP and mPAP increased from T30. While in TG, sPAP and mPAP increased from T75. In PG, heart rate (HR) increased from T30, in which PG was higher than TG. The TPRI values decreased from T30 in PG, and in TG, at T45, T60 and T90. In PG, at T0, PVRI was lower than at other times. In $\mathrm{PG}$, arterial partial pressures of oxygen $\left(\mathrm{PaO}_{2}\right)$ decreased from T60 and alveolar-arterial oxygen gradient $\left(\mathrm{PA}-\mathrm{aO}_{2}\right.$ ) increased at $\mathrm{T} 60$. In TG, at $\mathrm{T} 0 \mathrm{PaO}_{2}$ was higher than at $\mathrm{T} 30, \mathrm{~T} 45, \mathrm{~T} 60$ and $\mathrm{T} 90$, while $\mathrm{PA}-\mathrm{aO}_{2}$ at T0 was lower than at T90. From T30 to T90, TG showed higher $\mathrm{PaO}_{2}$ means and lower arterial partial pressures of carbon dioxide $\left(\mathrm{PaCO}_{2}\right)$ values when compared to PG. In PG, from T30, $\mathrm{PaCO}_{2}$ increased, while in TG this parameter was stable. In conclusion, thiopental anesthesia attenuated the cardiopulmonary changes resulting from serotonin-induced $\mathrm{PH}$, probably by attenuation of vasoconstriction and bronchoconstriction.
\end{abstract}

Keywords: dog, bispectral index, monitoring, serotonin, total intravenous anesthesia

\section{RESUMO}

Avaliaram-se as alterações cardiopulmonares em cães anestesiados com propofol ou tiopental induzidos à hipertensão pulmonar (HP). Vinte animais adultos foram distribuídos aleatoriamente em dois grupos: grupo propofol (PG) e grupo tiopental (TG). No PG, o propofol foi usado para indução (8 $\left.\pm 0,03 \mathrm{mg} \mathrm{kg}^{-1}\right)$ $e$ manutenção da anestesia $\left(0,8 \mathrm{mg} \mathrm{kg}^{-1}\right.$ minuto $\left.{ }^{-1}\right)$, enquanto no $T G$ foi empregado o tiopental $\left(22 \pm 2,92 \mathrm{mg} \mathrm{kg}^{-1} ; 0,5 \mathrm{mg} \mathrm{kg}^{-1}\right.$ minute $e^{-1}$, respectivamente). Em seguida, a ventilação mecânica ciclada a tempo foi iniciada. A HP foi induzida pela administração de serotonina (5HT) $\left(10 \mathrm{\mu g} \mathrm{kg}^{-1}\right.$ e $1 \mathrm{mg} \mathrm{kg}^{-}$ ${ }^{1}$ hour $\left.^{-1}\right)$ por meio de cateter de termodiluição posicionado na artéria pulmonar. As mensurações tiveram início antes da administração da 5HT (T0), depois de 30 minutos (T30), seguida de intervalos de 15

Recebido em 26 de fevereiro de 2014

Aceito em 10 de junho de 2014

E-mail: ferro_patricia@ig.com.br 
minutos (T45, T60, T75 e T90). Diferenças entre os grupos não foram registradas para pressões sistólica (PAPs) e média (PAPm) da artéria pulmonar, pressão arterial média (PAM), índices da resistência periférica total (IRPT) e da resistência vascular pulmonar (IRVP). A PAPs e a PAPm aumentaram a partir de T30, no PG, e a partir de T75, no TG. No PG, a frequência cardíaca (FC) aumentou a partir de T30, no qual PG foi maior que TG. O IRPT diminuiu no T45, T60 e T90, no TG, e a partir de T30 no PG. No PG, no T0, IRVP foi menor que nos outros momentos. No PG, a pressão parcial de oxigênio no sangue arterial $\left(\mathrm{PaO}_{2}\right)$ diminuiu a partir de T60, e a diferença de tensão entre o oxigênio alveolar e arterial $\left(\mathrm{PA}-\mathrm{aO}_{2}\right)$ aumentou no T60. No TG, no T0, a $\mathrm{PaO}_{2}$ foi maior que no T30, T45, T60 e T90, enquanto a PA-aO ', no T0, foi menor que no T90. Entre T30 e T90, TG apresentou maior $\mathrm{PaO}_{2}$ e menor pressão parcial de dióxido de carbono no sangue arterial $\left(\mathrm{PaCO}_{2}\right)$ quando comparado ao PG. No PG, a partir de T30, a $\mathrm{PaCO}_{2}$ aumentou. A anestesia com tiopental abrandou as mudanças cardiopulmonares resultantes da indução da HP pela serotonina, provavelmente devido à atenuação da vasoconstrição $e$ broncoconstrição.

Palavras-chave: cão, anestesia intravenosa total, índice biespectral, monitoramento, serotonina

\section{INTRODUCTION}

Pulmonary hypertension $(\mathrm{PH})$ is defined as increased blood pressure in the pulmonary vascular system and occurs as a primary or secondary disorder of this vasculature (Johnson et al., 1999). Most PH cases in dogs have been reported because of new technologies such as echocardiography. The signs of $\mathrm{PH}$ are cough, dyspnea, lethargy, exercise intolerance and cyanosis (Kellum and Stepien, 2007). In dogs, the most common reported causes of $\mathrm{PH}$ are heartworm disease, pulmonary thromboembolism, left-sided heart failure, chronic respiratory disease (Johnson et al., 1999).

In canines with $\mathrm{PH}$, hypoxemia is frequently present and its severity can indicate the degree of pulmonary dysfunction (Johnson, 1999). When systolic pulmonary arterial pressure (sPAP) exceeded $40 \mathrm{mmHg}$, there was a decrease in arterial partial pressure of oxygen $\left(\mathrm{PaO}_{2}\right)$, an increase in venous admixture and an increase in alveolar-arterial oxygen tension gradient (PA$\mathrm{aO}_{2}$ ) (Ellison et al., 1961).

The increased blood pulmonary pressure can be challenging for the anesthesiologist, who should improve oxygenation and decrease pulmonary vascular resistance (PVR) to avoid worsening the clinical condition. Anesthetic protocols can have an effect on PVR, cardiac output (CO), pulmonary blood flow, right ventricular afterload and potentially intra-cardiac shunting (Fischer $e t$ al., 2003).
Thus, there is no defined anesthetic protocol to follow for patients with PH. Studies in normal dogs have demonstrated that propofol has no effect on baseline PVR but causes pulmonary vasoconstriction when pulmonary vasomotor tone is acutely increased under conditions of alveolar hypoxia. Thiopental appears to have a dose dependent effect on the airway smooth muscle, causing bronchial constriction in small concentrations and relaxation in large concentrations (Okamura and Denborough, 1980).

This study was designed to assess cardiopulmonary changes in dogs anesthetized with propofol or thiopental, with and without serotonin (5HT) induced pulmonary hypertension.

\section{MATERIAL AND METHODS}

This study was approved by the Institutional Animal Care and Use Committee with protocol $\mathrm{n}^{\mathrm{o}}$ 017679-06. After the study the animals were available for adoption. All animals were determined to be healthy based on a complete physical examination, a cell blood count, standard serum biochemistry test, chest radiograph and electrocardiogram.

The dogs were kept in individual cages at the Veterinary Hospital and were provided with regular dog food (Pedigree ${ }^{\circledR}$ adulto carne \& marrowbone, Mars Brasil, Mogi Mirim, SP, Brazil) twice a day and water ad libitum. 
The animals were randomly assigned to two groups: propofol group (PG), ten dogs weighing $11.8 \pm 1.8 \mathrm{~kg}$ and thiopental group (TG), ten animals weighing $10.6 \pm 2.7 \mathrm{~kg}$. In $\mathrm{PG}$, anesthesia was induced with $8 \pm 0.03 \mathrm{mg} \mathrm{kg}^{-1}$ of propofol IV (Diprivan, Zeneca Farmacêutica do Brasil Ltda., São Paulo, SP, Brasil) administered over approximately one minute, the necessary dose for the animals to lose their laryngeal and tracheal reflexes. Immediately after induction, a continuous rate infusion (CRI) of propofol was administered at a rate of $0.8 \mathrm{mg} \mathrm{kg}^{-1}$ minute $^{-1}$, using an infusion pump (Infusion Pump 670T, Samtronic Ltda, São Paulo, SP, Brazil). In TG, thiopental (Tiopentax, Cristália Produtos Químicos Farmacêuticos Ltda, São Paulo, SP, Brazil) was used for induction $\left(22 \pm 2.92 \mathrm{mg} \mathrm{kg}^{-1}\right.$ IV), until the animals lost their laryngeal and tracheal reflexes, followed by a CRI $\left(0.5 \mathrm{mg} \mathrm{kg}^{-1}\right.$ minute $^{-1}$ ) using an infusion pump (Infusion Pump 670T, Samtronic Ltda, São Paulo, SP, Brazil).

After endotracheal intubation animals were placed on a time cycled mechanical ventilator (Inter Plus VAPS ventilador pulmonar, neonatal, pediátrico e adulto, Intermed, São Paulo, SP, Brazil) with inspired oxygen fraction $\left(\mathrm{FiO}_{2}\right)$ of 0.6 , the inspiratory time, respiratory rate and flow were adjusted and fixed to achieve an inspiratory to expiratory time ratio of $1: 2$ to $1: 3$ and end-tidal partial pressure of carbon dioxide $\left(\mathrm{PE}^{\prime} \mathrm{CO}_{2}\right)$ of 35 to $45 \mathrm{mmHg}$. The pressure limit was adjusted to $15 \mathrm{cmH}_{2} \mathrm{O}$. Adjustments were made in ventilation before the first measurement and before induction of pulmonary hypertension and no more adjustments were made thereafter. The sensor for the respiratory profile monitor (DX 8100, Dixtal, Manaus, AM, Brazil) was connected to the endotracheal tube to assess airway resistance (Raw) and peak inspiratory pressure (PIP).

The dogs were positioned in lateral recumbency on a heating pad. Then an intra-arterial catheter was placed in the right tarsal artery to assess mean arterial pressure (MAP) and to obtain arterial blood for measurements of the arterial partial pressures of carbon dioxide $\left(\mathrm{PaCO}_{2}\right)$, $\mathrm{PaO}_{2}$, arterial hemoglobin saturation $\left(\mathrm{SaO}_{2}\right)$ and pH (Roche Omni C blood gas analyzer; Roche Diagnostics, Mannheim, Germany). The blood gas analyzer calculated base deficit (BD) and bicarbonate concentration $\left(\mathrm{HCO}_{3}{ }^{-}\right)$. From these data, the following parameter was calculated:

$\mathrm{PA}-\mathrm{aO}_{2}=\mathrm{PAO}_{2}-\mathrm{PaO}_{2}$; where $\mathrm{PA}-\mathrm{aO}_{2}=$ alveolar-arterial oxygen gradient, $\mathrm{PaO}_{2}=$ arterial partial pressure of oxygen and $\mathrm{PAO}_{2}=$ alveolar partial pressure of oxygen, which was obtained by the following equation: $\mathrm{PAO}_{2}=\left[\mathrm{FiO}_{2} \times(\mathrm{Pb}-\right.$ 47)] - $\left(\mathrm{PaCO}_{2} / \mathrm{RQ}\right)$; where $\mathrm{Pb}=$ barometric pressure; $\mathrm{FiO}_{2}=$ inspired oxygen fraction; $\mathrm{PaCO}_{2}$ $=$ arterial partial pressure of carbon dioxide and $\mathrm{RQ}=$ respiratory quotient, which was assumed equal to 0.8 .

Next, an introducer (Cateter BD Insight 14, Becton, Dickinson Indústria Cirúrgica Ltda, Juiz de Fora, MG, Brazil) was placed percutaneously in the jugular vein, and through it a Swan-Ganz catheter (Catheter 132 - 5F, Edwards Lifesciences LLC, Irvine, CA, USA) was advanced to the lumen of the pulmonary artery. The catheter's position was confirmed by observation of characteristic changes in the pressure tracings as the catheter tip was advanced from the right ventricle into the pulmonary artery. Cardiac output was measured directly by the thermodilution technique with a microprocessor device (Dixtal mod. DX 2010, CO module, Manaus, AM, Brazil). Central venous pressure (CVP), sPAP, mPAP, diastolic pulmonary arterial pressure (dPAP) and pulmonary arterial occlusion pressure (PAOP) were measured via the thermodilution catheter.

Finally, pulmonary hypertension was induced with 5HT (H9523 Hydroxytryptamine Hydrochloride, Sigma-Aldrich Inc, Saint Louis, MO, USA) $10 \mu \mathrm{g} \mathrm{kg}^{-1}$ IV followed by an infusion of $1 \mathrm{mg} \mathrm{kg}^{-1}$ hour ${ }^{-1}$ via the pulmonary artery catheter's main branch (Hashimoto et al., 2000; Hirota et al., 2002) using an infusion pump (Bomba de seringa AS50, Samtronic $\AA$, São Paulo, SP, Brazil).

Venous blood was obtained from the catheter's distal port to evaluate the mixed venous oxygen partial pressure $\left(\mathrm{P} \overline{\mathrm{V}} \mathrm{O}_{2}\right)$, mixed venous carbon dioxide partial pressure $\left(\mathrm{P} \overline{\mathrm{V}} \mathrm{CO}_{2}\right)$, and mixed venous hemoglobin saturation $\left(\mathrm{S} \overline{\mathrm{V}} \mathrm{O}_{2}\right)$. For this, the infusion of serotonin was stopped. At the time of measurement, the pulmonary arterial limb hub was disconnected from the infusion pump and connected to the microprocessor 
device to record PAP and CVP. Next, we pulled all solutions inside the catheter (internal volume of catheter $=0.64 \mathrm{~mL}$ - Edwards Lifesciences Manual) with a $1 \mathrm{~mL}$ syringe, so a mixture of solution and blood was obtained. Following, 2 $\mathrm{mL}$ of venous blood was collected to remove the blood diluted by solution of 5HT. After that, in a syringe $(1 \mathrm{~mL})$ with heparin, a sample of mixed venous blood was obtained from the catheter's distal port for measurements of blood gas variables (Roche Omni C blood gas analyzer; Roche Diagnostics, Mannheim, Germany). Finally, cardiac output was measured and then the $2 \mathrm{~mL}$ of blood and the $1 \mathrm{~mL}$ of $5 \mathrm{HT}$ solution (with blood) previously collected were reinjected, respectively, through the catheter's pulmonary port. This port was connected again to the infusion pump to restart the CRI of serotonin. A single veterinary anesthesiologist performed this sequence.

Heart rate (HR) was measured using a computerized electrocardiograph adjusted to lead II. Cardiac index (CI), pulmonary vascular resistance index (PVRI) and total peripheral resistance index (TPRI) were calculated using the following formulas: $\mathrm{CI}=\mathrm{CO} / \mathrm{BSA}$, where BSA (body surface area) $=$ weight $^{0.6667} / 10$; PVRI $=\{[(\mathrm{mPAP}-\mathrm{PAOP}) / \mathrm{CO}] \times 79.9\} \times \mathrm{BSA} ; \mathrm{TPRI}$ $=[(\mathrm{MAP} / \mathrm{CO}) * 79.9] \times \mathrm{BSA}$.

The bispectral index (BIS) was computed by an Aspect A-2000 monitor (A 2000 XP Bispectral Index Monitor Systems, Inc. Natick, MA, EUA). The signal was acquired with electrodes (Sensor; Aspect Medical Systems, Inc, Natick, MA, USA) placed as described by Lopes et al. (2008a). The values of BIS were recorded.

The first measurement of parameters was performed before beginning of continuous infusion of serotonin (T0), after 30 minutes (T30) and then at 15-minute intervals for another 60 minutes (T45, T60, T75 and T90, respectively).

The D'Agostino-Pearson omnibus test was used to confirm that data fit a standard normal distribution $(\mathrm{P}>0.05)$. Following the test, numerical data were subjected to One-way Analysis of Variance (ANOVA) to determine difference between the different time points of the same group. Two-way ANOVA was used among groups. Bonferroni test was used for posthoc multiple comparisons at a $\alpha$ level of 0.05 . Analyses were performed using Prism 5 for Windows (GraphPad Software Inc, CA, USA).

\section{RESULTS AND DISCUSSION}

The signs of $\mathrm{PH}$ are dyspnea, fatigue (Fischer et al., 2003), cough, "raspy" breathing, ausculted pulmonary crackels, syncope or collapse episodes and others (Kellum and Stepien, 2007). In patients with $\mathrm{PH}$, the chest radiograph can display an enlarged main pulmonary artery, enlarged hilar vessels, right ventricular enlargement (Johnson, 1999; Fischer et al., 2003) pulmonary infiltrate and other less common abnormal pulmonary findings (narrow trachea, atelectasis, pulmonary mass lesion, bronchiectasis, rounding of the lung lobes) (Kellum and Stepien, 2007) whereas the electrocardiogram shows a right axis deviation suggesting right ventricular hypertrophy (Fischer et al., 2003). Thus, before the procedure physical examination, electrocardiographic and thoracic radiographic examinations were all carried out. If some dogs showed these signs they were removed from this study. However, the definitive diagnosis of $\mathrm{PH}$ is obtained by heart catheterization with direct measurement of PAP (Fischer et al., 2003), so at T0 we could confirm that dogs did not have PH, because PAP values were normal (Table 1).

The BIS has been used successfully as an indicator of the level of sedation and hypnosis (Lopes et al., 2008a). Thiopental induced BIS changes closely corresponding to those of propofol in humans (Vuyk and Schraag, 2003). Using the bispectral index, the pilot study was performed to obtain CRI of propofol or thiopental that produced equivalent degrees of hypnosis (values of BIS between 65 and 75). CRI of $0.5 \mathrm{mg} \mathrm{kg}^{-1}$ minute ${ }^{-1}$ for thiopental and 0.8 $\mathrm{mg} \mathrm{kg}^{-1}$ minute $^{-1}$ for propofol were found. Thus, in this study, doses of propofol and thiopental were used to produce similar BIS values and, consequently, the same level of hypnosis (Table 1). Additionally, BIS was used to evaluate whether continuous infusion of serotonin could 
change the drugs' depressant effects on the central nervous system (CNS).

In dogs, an increase in the propofol infusion rate is related to a decrease in the BIS values (Lopes et al., 2008b). However, in this study, the same dose of propofol used during the whole procedure explained the BIS' stability observed in PG. In TG the BIS decreased at T75 and at T90 when compared to T0 and T30 (Table 1). This event was attributed to a cumulative effect of thiopental (Branson, 2007). In both groups serotonin did not change the BIS values.

Table 1. Bispectral index and cardiovascular parameters in propofol (PG) or thiopental (TG) anesthetized dogs subject to serotonin-induced pulmonary arterial hypertension

\begin{tabular}{|c|c|c|c|c|c|c|c|c|}
\hline \multirow{2}{*}{ Parameters } & & \multicolumn{6}{|c|}{ Times } & \multirow{2}{*}{$\begin{array}{c}\mathrm{p} \text { value } \\
\text { (time } \mathrm{x} \text { time) }\end{array}$} \\
\hline & & T0 & $\mathrm{T} 30$ & $\mathrm{~T} 45$ & T60 & $\mathrm{T} 75$ & $\mathrm{~T} 90$ & \\
\hline \multirow[t]{2}{*}{ BIS } & PG & $70 \pm 11$ & $69 \pm 12$ & $67 \pm 11$ & $67 \pm 11$ & $68 \pm 11$ & $67 \pm 12$ & $\mathrm{P}>0.05$ \\
\hline & TG & $71 \pm 6 a$ & $71 \pm 8 \mathrm{a}$ & $69 \pm 7$ & $67 \pm 8$ & $65 \pm 7 b$ & $65 \pm 6 \mathrm{~b}$ & $\mathrm{P}<0.05$ \\
\hline $\mathrm{p}$ value (group x group) & & $\mathrm{P}>0.05$ & $\mathrm{P}>0.05$ & $\mathrm{P}>0.05$ & $\mathrm{P}>0.05$ & $\mathrm{P}>0.05$ & $\mathrm{P}>0.05$ & \\
\hline HR & PG & $114 \pm 22 \mathrm{a}$ & $149 \pm 13 \mathrm{Ab}$ & $143 \pm 18 \mathrm{Ab}$ & $142 \pm 25 \mathrm{Ab}$ & $144 \pm 22 \mathrm{Ab}$ & $143 \pm 19 \mathrm{Ab}$ & $\mathrm{P}<0.05$ \\
\hline (beats minute $^{-1}$ ) & TG & $90 \pm 23$ & $113 \pm 29 \mathrm{~B}$ & $112 \pm 20 \mathrm{~B}$ & $111 \pm 20 \mathrm{~B}$ & $103 \pm 22 \mathrm{~B}$ & $104 \pm 24 \mathrm{~B}$ & $\mathrm{P}>0.05$ \\
\hline $\mathrm{p}$ value (group $\mathrm{x}$ group) & & $\mathrm{P}>0.05$ & $\mathrm{P}<0.01$ & $\mathrm{P}<0.05$ & $\mathrm{P}<0.05$ & $\mathrm{P}<0.001$ & $\mathrm{P}<0.001$ & \\
\hline MAP & $\mathrm{PG}$ & $79 \pm 14$ & $74 \pm 27$ & $77 \pm 22$ & $74 \pm 20$ & $75 \pm 20$ & $76 \pm 21$ & $\mathrm{P}>0.05$ \\
\hline$(\mathrm{mmHg})$ & TG & $90 \pm 13$ & $89 \pm 26$ & $90 \pm 21$ & $81 \pm 26$ & $83 \pm 29$ & $83 \pm 34$ & $\mathrm{P}>0.05$ \\
\hline $\mathrm{p}$ value (group $\mathrm{x}$ group) & & $\mathrm{P}>0.05$ & $\mathrm{P}>0.05$ & $\mathrm{P}>0.05$ & $\mathrm{P}>0.05$ & $\mathrm{P}>0.05$ & $\mathrm{P}>0.05$ & \\
\hline sPAP & $\mathrm{PG}$ & $18 \pm 5 \mathrm{a}$ & $32 \pm 8 \mathrm{~b}$ & $32 \pm 6 \mathrm{~b}$ & $32 \pm 7 \mathrm{~b}$ & $32 \pm 6 \mathrm{~b}$ & $32 \pm 7 \mathrm{~b}$ & $\mathrm{P}<0.05$ \\
\hline$(\mathrm{mmHg})$ & TG & $18 \pm 4 \mathrm{a}$ & $28 \pm 10$ & $26 \pm 4$ & $27 \pm 5$ & $32 \pm 16 b$ & $34 \pm 16 b$ & $\mathrm{P}<0.05$ \\
\hline $\mathrm{p}$ value (group $\mathrm{x}$ group) & & $\mathrm{P}>0.05$ & $\mathrm{P}>0.05$ & $\mathrm{P}>0.05$ & $\mathrm{P}>0.05$ & $\mathrm{P}>0.05$ & $\mathrm{P}>0.05$ & \\
\hline dPAP & $\mathrm{PG}$ & $8 \pm 5 a$ & $12 \pm 6 \mathrm{~b}$ & $11 \pm 6 \mathrm{~b}$ & $12 \pm 6 \mathrm{~b}$ & $12 \pm 5 \mathrm{~b}$ & $12 \pm 4 \mathrm{~b}$ & $\mathrm{P}<0.05$ \\
\hline$(\mathrm{mmHg})$ & TG & $9 \pm 3 a$ & $14 \pm 6 b$ & $11 \pm 3$ & $11 \pm 2$ & $11 \pm 4$ & $12 \pm 4$ & $\mathrm{P}<0.05$ \\
\hline $\mathrm{p}$ value (group $\mathrm{x}$ group) & & $\mathrm{P}>0.05$ & $\mathrm{P}>0.05$ & $\mathrm{P}>0.05$ & $\mathrm{P}>0.05$ & $\mathrm{P}>0.05$ & $\mathrm{P}>0.05$ & \\
\hline mPAP & $P G$ & $13 \pm 5 \mathrm{a}$ & $21 \pm 6 b$ & $21 \pm 6 \mathrm{~b}$ & $21 \pm 6 \mathrm{~b}$ & $21 \pm 5 b$ & $21 \pm 6 b$ & $\mathrm{P}<0.05$ \\
\hline$(\mathrm{mmHg})$ & TG & $14 \pm 4 \mathrm{a}$ & $20 \pm 7$ & $18 \pm 3$ & $19 \pm 3$ & $21 \pm 7 b$ & $21 \pm 6 b$ & $\mathrm{P}<0.05$ \\
\hline $\mathrm{p}$ value (group $\mathrm{x}$ group) & & $\mathrm{P}>0.05$ & $\mathrm{P}>0.05$ & $\mathrm{P}>0.05$ & $\mathrm{P}>0.05$ & $\mathrm{P}>0.05$ & $\mathrm{P}>0.05$ & \\
\hline PAOP & $\mathrm{PG}$ & $6 \pm 4$ & $5 \pm 4$ & $5 \pm 4$ & $6 \pm 3$ & $6 \pm 4$ & $6 \pm 4$ & $\mathrm{P}>0.05$ \\
\hline$(\mathrm{mmHg})$ & TG & $7 \pm 3$ & $8 \pm 4$ & $9 \pm 4$ & $9 \pm 4$ & $8 \pm 5$ & $9 \pm 4$ & $\mathrm{P}>0.05$ \\
\hline $\mathrm{p}$ value (group $\mathrm{x}$ group) & & $\mathrm{P}>0.05$ & $\mathrm{P}>0.05$ & $\mathrm{P}>0.05$ & $\mathrm{P}>0.05$ & $\mathrm{P}>0.05$ & $\mathrm{P}>0.05$ & \\
\hline CVP & PG & $3 \pm 4$ & $2 \pm 4$ & $3 \pm 4$ & $3 \pm 4$ & $2 \pm 4$ & $3 \pm 4$ & $\mathrm{P}>0.05$ \\
\hline (mmHg) & TG & $5 \pm 2$ & $5 \pm 2$ & $5 \pm 1$ & $5 \pm 1$ & $4 \pm 2$ & $5 \pm 2$ & $\mathrm{P}>0.05$ \\
\hline $\mathrm{p}$ value (group $\mathrm{x}$ group) & & $\mathrm{P}>0.05$ & $\mathrm{P}>0.05$ & $\mathrm{P}>0.05$ & $\mathrm{P}>0.05$ & $\mathrm{P}>0.05$ & $\mathrm{P}>0.05$ & \\
\hline CI & $P G$ & $4.0 \pm 0.9 \mathrm{a}$ & $5.1 \pm 1.5 b$ & $5.2 \pm 1.4 \mathrm{~b}$ & $5.4 \pm 1.0 \mathrm{~b}$ & $5.2 \pm 1.1 \mathrm{~b}$ & $5.5 \pm 1.1 \mathrm{~b}$ & $\mathrm{P}<0.05$ \\
\hline$\left(\mathrm{L} \mathrm{minute}^{-1} \mathrm{~m}^{-2}\right)$ & TG & $3.5 \pm 0.8 \mathrm{a}$ & $4.8 \pm 1.0 \mathrm{~b}$ & $4.9 \pm 0.9 \mathrm{~b}$ & $5.0 \pm 1.1 \mathrm{~b}$ & $4.4 \pm 1.0$ & $4.5 \pm 0.9 \mathrm{~b}$ & $\mathrm{P}<0.05$ \\
\hline $\mathrm{p}$ value (group $\mathrm{x}$ group) & & $\mathrm{P}>0.05$ & $\mathrm{P}>0.05$ & $\mathrm{P}>0.05$ & $\mathrm{P}>0.05$ & $\mathrm{P}>0.05$ & $\mathrm{P}>0.05$ & \\
\hline TPRI & PG & $1618 \pm 330 \mathrm{a}$ & $1212 \pm 470 \mathrm{~b}$ & $1227 \pm 410 \mathrm{~b}$ & $1132 \pm 310 \mathrm{~b}$ & $1192 \pm 322 b$ & $1126 \pm 325 b$ & $\mathrm{P}<0.05$ \\
\hline (dynes seconds $\mathrm{cm}^{-5} \mathrm{~m}^{-2}$ ) & TG & $2122 \pm 414 \mathrm{a}$ & $1612 \pm 762$ & $1525 \pm 457 \mathrm{~b}$ & $1403 \pm 608 \mathrm{~b}$ & $1628 \pm 783$ & $1500 \pm 607 \mathrm{~b}$ & $\mathrm{P}<0.05$ \\
\hline $\mathrm{p}$ value (group $\mathrm{x}$ group) & & $\mathrm{P}>0.05$ & $\mathrm{P}>0.05$ & $\mathrm{P}>0.05$ & $\mathrm{P}>0.05$ & $\mathrm{P}>0.05$ & $\mathrm{P}>0.05$ & \\
\hline PVRI & PG & $156 \pm 72 \mathrm{a}$ & $287 \pm 128 b$ & $252 \pm 105 b$ & $241 \pm 95 b$ & $248 \pm 98 b$ & $234 \pm 109 \mathrm{~b}$ & $\mathrm{P}<0.05$ \\
\hline (dynes seconds $\mathrm{cm}^{-5} \mathrm{~m}^{-2}$ ) & TG & $153 \pm 63$ & $205 \pm 84$ & $166 \pm 92$ & $177 \pm 118$ & $240 \pm 133$ & $226 \pm 133$ & $\mathrm{P}<0.05$ \\
\hline $\mathrm{p}$ value (group $\mathrm{x}$ group) & & $\mathrm{P}>0.05$ & $\mathrm{P}>0.05$ & $\mathrm{P}>0.05$ & $\mathrm{P}>0.05$ & $\mathrm{P}>0.05$ & $\mathrm{P}>0.05$ & \\
\hline
\end{tabular}

The results are given as mean \pm SD. Means with different capital letters within each column and with different lower case letters within each row differed significantly. T0: time of measurements before pulmonary hypertension induction, T30: after 30 minutes of beginning continuous infusion of serotonin, T45 to T90: times of measurements taken 15 to 60 min after T30. BIS: value of bispectral index medium, HR: heart rate, systolic arterial pressure, DAP: diastolic arterial pressure, MAP: mean arterial pressure, sPAP: systolic pulmonary pressure, dPAP: diastolic pulmonary arterial pressure; mPAP: mean pulmonary arterial pressure, POAP: pulmonary arterial occlusion pressure, CI: cardiac index, TPRI: total peripheral resistance index, PVRI: pulmonary vascular resistance index.

In this study no differences between groups were registered for SPAP, dPAP and mPAP. However, in $\mathrm{PG}$, sPAP, dPAP and mPAP increased from T30; while in TG sPAP, dPAP and mPAP increased from $\mathrm{T} 75$, at $\mathrm{T} 30$ and from $\mathrm{T} 75$, respectively (Table 1 ). In a study of $\mathrm{PH}$ in dogs, authors used as reference values of sPAP and dPAP greater than 30 and $19 \mathrm{mmHg}$ assessed using ultrasound, respectively (Kellum and Stepien, 2007). According to Johnson (1999) there is PH when sPAP and/or mPAP are above 30 and $20 \mathrm{mmHg}$, respectively, but its values were based on humans not on dogs. Although our values did not meet the definition of $\mathrm{PH}$ in people or by Kellum and Stepien (2007) the values were significantly different from the 
baseline. After 30 minutes of continuous infusion of 5HT, pulmonary arterial pressure increased significantly and remained at this increased value until the end of the procedure. After the last measurement of parameters (T90), the infusion of serotonin was finished and the values of PAP returned to baseline over about 20 minutes in both groups. A similar duration of action was seen in rabbits (Nozik-Grayck et al., 2002).

In the propofol group, HR increased from T30 (Table 1). Serotonin administration is associated with an increase in HR (Frishman and Grewall 2000) and this was observed in this study. However, in TG, HR was stable. And from T30, PG was higher than TG (Table 1). Thus, it is believed that the dose of barbiturate attenuated the serotonin effect on HR in TG, and the stronger action of 5HT on $\mathrm{PG}$ promoted a difference between groups.

No differences between these groups were observed for CI, MAP and TPRI (Table 1). Cardiac index also increased after infusion of 5HT in both groups (Table 1). This was also observed by Yoshioka et al. (2001) in pentobarbital-anesthetized dogs induced to pulmonary hypertension. Sawyer (1998) stated that propofol is more of a vasodilator than thiopental. There were no differences in TPRI between PG and TG during the whole procedure (Table 1). Therefore, Sawyer's statement was not confirmed by this study's data. In PG, TPRI decreased from T30, while in TG, this parameter decreased at T45, T60 and T90 (Table1). In both groups TPRI decreased due to increased CI. Hashiba et al. (2000), Hashimoto et al. (2000) and Yoshioka et al. (2001) also observed a decrease in systemic vascular resistance in pentobarbital-anesthetized dogs induced to $\mathrm{PH}$ by a CRI of $5 \mathrm{HT}$.

For PVRI no differences between groups were observed. In PG, at T0 PVRI was lower than at
T30, T45, T60, T75 and T90 (Table 1). In TG, PVRI did not increase significantly, but in both groups the increase of this parameter was due to $\mathrm{PH}$. In this study, in PG, at T30, PVRI increased $\pm 84 \%$; while in $\mathrm{TG}$ they increased $\pm 32 \%$. Yoshioka et al. (2001) had an increase of 55\%. In TG the PVRI increase (32\%) was probably lower than in PG (84\%) because the administered thiopental dose had attenuated the serotonin-induced pulmonary vasoconstriction. Gross and Abel (1985) found that less than $3 \mathrm{x}$ $10^{-4} \mathrm{M}$ thiopental concentration-dependently potentiated serotonin-induced contraction of the rabbit basilar artery, whereas more than $3 \times 10^{-4}$ $M$ thiopental dose-dependently relaxed it. In a study with three vasoconstrictors (serotonin, histamine and acetylcholine), Klockgether-Radke et al. (2000) concluded that this thiobarbiturate relaxes isolated coronary segments in a dose-dependent manner, and there was no evidence that these effects were dependent on endothelial factors. Thus, considering the animal preparation and times of measurement, the high concentration of this drug may have attenuated the serotonin-induced pulmonary vasoconstriction.

According to Hirota et al. (2002) and Hashimoto et al. (2000), when $\mathrm{PH}$ is induced by serotonin, the bronchial cross-sectional area (BCA) decreases by $50 \%$ and Raw increases as described by the Hagen-Poiseuille law (McDonell and Kerr, 2007). Therefore, the BCA should be decreased in this study, because the protocol used to induce $\mathrm{PH}$ was the same cited by these authors. Thus, in PG, Raw increased at T45 (Table 2). However, clinically, Raw increased in both groups after $\mathrm{PH}$ induction. When Raw is higher, the pressure to expand lungs needs to be higher (Bonassa, 2006). This event reflected in PIP means increase observed in both groups (Table 2). 
Cardiopulmonary parameters...

Table 2. Airway resistance, peak inspiratory pressure and blood gas parameters in propofol (PG) or thiopental (TG) anesthetized dogs subject to serotonin-induced pulmonary arterial hypertension

\begin{tabular}{|c|c|c|c|c|c|c|c|c|}
\hline \multirow{2}{*}{ Parameters } & & \multicolumn{6}{|c|}{ Times } & \multirow{2}{*}{$\begin{array}{c}\mathrm{p} \text { value } \\
\text { (time } \mathrm{x} \text { time) }\end{array}$} \\
\hline & & T0 & T30 & T45 & T60 & T75 & T90 & \\
\hline Raw & PG & $20 \pm 7 \mathrm{a}$ & $22 \pm 7$ & $27 \pm 13 \mathrm{Ab}$ & $26 \pm 11$ & $25 \pm 7$ & $25 \pm 7$ & $\mathrm{P}<0.05$ \\
\hline$\left(\mathrm{cmH}_{2} \mathrm{O} \mathrm{L}^{-1}\right.$ second $\left.^{-1}\right)$ & TG & $13 \pm 8$ & $16 \pm 7$ & $15 \pm 7 \mathrm{~B}$ & $18 \pm 11$ & $15 \pm 7$ & $16 \pm 7$ & $\mathrm{P}>0.05$ \\
\hline $\mathrm{p}$ value (group $\mathrm{x}$ group) & & $\mathrm{P}>0.05$ & $\mathrm{P}>0.05$ & $\mathrm{P}<0.01$ & $\mathrm{P}>0.05$ & $\mathrm{P}>0.05$ & $\mathrm{P}>0.05$ & \\
\hline PIP & PG & $12 \pm 2 \mathrm{a}$ & $13 \pm 1 b$ & $13 \pm 1 b$ & $13 \pm 1 b$ & $13 \pm 1 \mathrm{~b}$ & $13 \pm 2 b$ & $\mathrm{P}<0.05$ \\
\hline$\left(\mathrm{cmH}_{2} \mathrm{O}\right)$ & TG & $11 \pm 2 \mathrm{a}$ & $12 \pm 1 \mathrm{~b}$ & $12 \pm 2 b$ & $12 \pm 1 \mathrm{~b}$ & $12 \pm 2 b$ & $12 \pm 1 \mathrm{~b}$ & $\mathrm{P}<0.05$ \\
\hline $\mathrm{p}$ value (group $\mathrm{x}$ group) & & $\mathrm{P}>0.05$ & $\mathrm{P}>0.05$ & $\mathrm{P}>0.05$ & $\mathrm{P}>0.05$ & $\mathrm{P}>0.05$ & $\mathrm{P}>0.05$ & \\
\hline $\mathrm{PaO}_{2}$ & PG & $281 \pm 39 \mathrm{a}$ & $246 \pm 61 \mathrm{~B}$ & $225 \pm 56 \mathrm{~B}$ & $217 \pm 59 \mathrm{Bb}$ & $217 \pm 65 \mathrm{Bb}$ & $218 \pm 69 \mathrm{Bb}$ & $\mathrm{P}<0.05$ \\
\hline$(\mathrm{mmHg})$ & TG & $312 \pm 17 \mathrm{a}$ & $300 \pm 16 \mathrm{~A}$ & $289 \pm 28 \mathrm{Ab}$ & $291 \pm 23 \mathrm{Ab}$ & $295 \pm 20 \mathrm{~A}$ & $284 \pm 29 \mathrm{Ab}$ & $\mathrm{P}<0.05$ \\
\hline $\mathrm{p}$ value (group $\mathrm{x}$ group) & & $P>0.05$ & $\mathrm{P}<0.05$ & $\mathrm{P}<0.01$ & $\mathrm{P}<0.01$ & $\mathrm{P}<0.01$ & $\mathrm{P}<0.01$ & \\
\hline $\mathrm{PaCO}_{2}$ & PG & $47 \pm 3 a$ & $51 \pm 6 \mathrm{~A}$ & $54 \pm 7 \mathrm{Ab}$ & $52 \pm 9$ & $54 \pm 9 \mathrm{Ab}$ & $55 \pm 9 \mathrm{Ab}$ & $\mathrm{P}<0.05$ \\
\hline$(\mathrm{mmHg})$ & TG & $41 \pm 2 \mathrm{a}$ & $44 \pm 3 \mathrm{Bb}$ & $45 \pm 5 \mathrm{Bb}$ & $46 \pm 4 \mathrm{~b}$ & $46 \pm 4 \mathrm{Bb}$ & $47 \pm 4 \mathrm{Bb}$ & $\mathrm{P}<0.05$ \\
\hline $\mathrm{p}$ value (group $\mathrm{x}$ group) & & $\mathrm{P}>0.05$ & $\mathrm{P}<0.05$ & $\mathrm{P}<0.01$ & $\mathrm{P}>0.05$ & $\mathrm{P}<0.05$ & $\mathrm{P}<0.05$ & \\
\hline $\mathrm{SaO}_{2}$ & PG & $98 \pm 1 \mathrm{a}$ & $98 \pm 1$ & $98 \pm 2 \mathrm{~B}$ & $97 \pm 2 B$ & $97 \pm 2 B$ & $96 \pm 2 \mathrm{Bb}$ & $\mathrm{P}<0.05$ \\
\hline$(\%)$ & TG & $99 \pm 1$ & $99 \pm 1$ & $99 \pm 1 \mathrm{~A}$ & $99 \pm 1 \mathrm{~A}$ & $99 \pm 1 \mathrm{~A}$ & $99 \pm 1 \mathrm{~A}$ & $\mathrm{P}>0.05$ \\
\hline $\mathrm{p}$ value (group $\mathrm{x}$ group) & & $\mathrm{P}>0.05$ & $\mathrm{P}>0.05$ & $\mathrm{P}<0.05$ & $\mathrm{P}>0.001$ & $P<0.001$ & $\mathrm{P}<0.001$ & \\
\hline & PG & $7.329 \pm 0.021 \mathrm{a}$ & $7.281 \pm 0.052 b$ & $7.242 \pm 0.059 \mathrm{Bbc}$ & $7.241 \pm 0.064 \mathrm{Bbc}$ & $7.234 \pm 0.067 \mathrm{Bc}$ & $7.215 \pm 0.080 \mathrm{Bc}$ & $\mathrm{P}<0.05$ \\
\hline $\mathrm{pH}$ & TG & $7.372 \pm 0.024 \mathrm{a}$ & $7.339 \pm 0.035 \mathrm{~b}$ & $7.331 \pm 0.047 \mathrm{Ab}$ & $7.326 \pm 0.047 \mathrm{Ab}$ & $7.324 \pm 0.046 \mathrm{Ab}$ & $7.319 \pm 0.042 \mathrm{Ab}$ & $\mathrm{P}<0.05$ \\
\hline $\mathrm{p}$ value (group $\mathrm{x}$ group) & & $\mathrm{P}>0.05$ & $\mathrm{P}>0.05$ & $\mathrm{P}<0.01$ & $\mathrm{P}>0.01$ & $\mathrm{P}<0.01$ & $\mathrm{P}<0.001$ & \\
\hline BD & PG & $-1.9 \pm 1.5 \mathrm{a}$ & $-4.0 \pm 1.7 b$ & $-5.3 \pm 1.9 \mathrm{Bc}$ & $-6.1 \pm 1.7 \mathrm{Bcd}$ & $-6.1 \pm 1.8 \mathrm{Bcd}$ & $-6.9 \pm 2.6 \mathrm{Bd}$ & $\mathrm{P}<0.05$ \\
\hline$\left(\mathrm{mEq} \mathrm{L}{ }^{-1}\right)$ & TG & $-1.8 \pm 1.9 \mathrm{a}$ & $-2.7 \pm 1.6 \mathrm{~b}$ & $-2.5 \pm 1.7 \mathrm{Ab}$ & $-2.8 \pm 1.9 \mathrm{Ab}$ & $-2.8 \pm 1.8 \mathrm{Ab}$ & $-2.8 \pm 1.9 \mathrm{Ab}$ & $\mathrm{P}<0.05$ \\
\hline $\mathrm{p}$ value (group $\mathrm{x}$ group) & & $P>0.05$ & $\mathrm{P}>0.05$ & $\mathrm{P}<0.01$ & $\mathrm{P}>0.001$ & $\mathrm{P}<0.001$ & $\mathrm{P}<0.001$ & \\
\hline $\mathrm{HCO}_{3}{ }^{-}$ & PG & $24.0 \pm 1.7 \mathrm{a}$ & $23.0 \pm 1.5 \mathrm{~b}$ & $22.3 \pm 1.4 \mathrm{bd}$ & $21.3 \pm 1.4 \mathrm{Bc}$ & $21.5 \pm 1.2 \mathrm{~cd}$ & $21.1 \pm 1.6 \mathrm{Bc}$ & $\mathrm{P}<0.05$ \\
\hline$\left(\mathrm{mEq} \mathrm{L}{ }^{-1}\right)$ & TG & $23.1 \pm 1.7$ & $23.0 \pm 1.4$ & $23.3 \pm 1.4$ & $23.2 \pm 1.5 \mathrm{~A}$ & $23.2 \pm 1.4$ & $23.2 \pm 1.6 \mathrm{~A}$ & $P>0.05$ \\
\hline $\mathrm{p}$ value (group $\mathrm{x}$ group) & & $\mathrm{P}>0.05$ & $\mathrm{P}>0.05$ & $\mathrm{P}>0.05$ & $\mathrm{P}<0.05$ & $\mathrm{P}>0.05$ & $\mathrm{P}<0.05$ & \\
\hline $\mathrm{P} \overline{\mathrm{V}} \mathrm{O}_{2}$ & PG & $63.6 \pm 8.9 \mathrm{Aa}$ & $70.4 \pm 6.5 \mathrm{Ab}$ & $70.0 \pm 7.4 \mathrm{Ab}$ & $71.4 \pm 5.9 \mathrm{Ab}$ & $70.9 \pm 7.2 \mathrm{Ab}$ & $72.4 \pm 7.0 \mathrm{Ab}$ & $\mathrm{P}<0.05$ \\
\hline (mmHg) & TG & $53.9 \pm 4.1 \mathrm{Ba}$ & $59.8 \pm 6.4 \mathrm{Bb}$ & $58.0 \pm 3.5 \mathrm{~B}$ & $57.1 \pm 3.0 \mathrm{~B}$ & $56.2 \pm 2.1 \mathrm{~B}$ & $56.8 \pm 2.5 \mathrm{~B}$ & $\mathrm{P}<0.05$ \\
\hline $\mathrm{p}$ value (group $\mathrm{x}$ group) & & $\mathrm{P}<0.01$ & $\mathrm{P}<0.001$ & $\mathrm{P}<0.001$ & $\mathrm{P}<0.001$ & $\mathrm{P}<0.001$ & $\mathrm{P}<0.001$ & \\
\hline $\mathrm{P} \overline{\mathrm{V}} \mathrm{CO}_{2}$ & PG & $54.6 \pm 4.3 \mathrm{a}$ & $58.8 \pm 6.2 \mathrm{~A}$ & $60.3 \pm 7.8 \mathrm{Ab}$ & $61.0 \pm 7.6 \mathrm{Ab}$ & $59.3 \pm 9.1 \mathrm{~b}$ & $60.9 \pm 8.8 \mathrm{~b}$ & $\mathrm{P}<0.05$ \\
\hline$(\mathrm{mmHg})$ & TG & $46.3 \pm 3.3 \mathrm{a}$ & $47.8 \pm 5.8 \mathrm{Bac}$ & $50.5 \pm 5.7 \mathrm{~B}$ & $51.7 \pm 5.9 \mathrm{Bbc}$ & $53.1 \pm 8.2 \mathrm{~b}$ & $53.6 \pm 7.9 \mathrm{~b}$ & $\mathrm{P}<0.05$ \\
\hline $\mathrm{p}$ value (group $\mathrm{x}$ group) & & $\mathrm{P}>0.05$ & $\mathrm{P}<0.01$ & $\mathrm{P}<0.05$ & $\mathrm{P}<0.05$ & $\mathrm{P}>0.05$ & $\mathrm{P}>0.05$ & \\
\hline $\mathrm{S} \overline{\mathrm{V}} \mathrm{O}_{2}$ & PG & $81.4 \pm 2.8$ & $83.3 \pm 3.2$ & $79.8 \pm 6.5$ & $79.9 \pm 6.9$ & $79.2 \pm 8.0$ & $79.3 \pm 9.2$ & $\mathrm{P}>0.05$ \\
\hline$(\%)$ & TG & $74.6 \pm 5.1 \mathrm{~b}$ & $79.2 \pm 6.5 \mathrm{a}$ & $77.8 \pm 4.9$ & $76.6 \pm 4.5$ & $75.3 \pm 5.4$ & $75.0 \pm 5.3 \mathrm{~b}$ & $\mathrm{P}<0.05$ \\
\hline $\mathrm{p}$ value (group $\mathrm{x}$ group) & & $\mathrm{P}>0.05$ & $\mathrm{P}>0.05$ & $\mathrm{P}>0.05$ & $\mathrm{P}>0.05$ & $\mathrm{P}>0.05$ & $\mathrm{P}>0.05$ & \\
\hline $\mathrm{PA}-\mathrm{aO}_{2}$ & PG & $61 \pm 40 \mathrm{a}$ & $91 \pm 57$ & $108 \pm 50 \mathrm{~A}$ & $119 \pm 54 \mathrm{Ab}$ & $116 \pm 57 \mathrm{~A}$ & $114 \pm 60 \mathrm{~A}$ & $\mathrm{P}<0.05$ \\
\hline$(\mathrm{mmHg})$ & TG & $37 \pm 16 \mathrm{a}$ & $45 \pm 15$ & $53 \pm 27 \mathrm{~B}$ & $51 \pm 20 \mathrm{~B}$ & $47 \pm 18 \mathrm{~B}$ & $57 \pm 28 \mathrm{Bb}$ & $\mathrm{P}<0.05$ \\
\hline $\mathrm{p}$ value (group $\mathrm{x}$ group) & & $\mathrm{P}>0.05$ & $\mathrm{P}>0.05$ & $\mathrm{P}<0.05$ & $\mathrm{P}<0.01$ & $\mathrm{P}<0.01$ & $\mathrm{P}<0.05$ & \\
\hline
\end{tabular}

The results are given as mean \pm SD. Means with different capital letters within each column and with different lower case letters within each row differed significantly. T0 - time of measurements before pulmonary hypertension induction; T30 - after 30 minutes of beginning continuous infusion of serotonin; T45 to T90 - times of measurements taken 15 to 60 min after T30; Raw - airway resistance, PIP - peak inspiratory pressure; $\mathrm{PaO}_{2}$-arterial oxygen partial pressure; $\mathrm{PaCO}_{2}$ - arterial carbon dioxide partial pressure; $\mathrm{SaO}_{2}$ - hemoglobin saturation; $\mathrm{BD}$ - base deficit; $\mathrm{HCO}_{3}{ }^{-}$- bicarbonate concentration; $\mathrm{PvO}_{2}$ - venous oxygen partial pressure; $\mathrm{PvCO}_{2}$ - venous carbon dioxide partial pressure; $\mathrm{SvO}_{2}$ - venous hemoglobin saturation; $\mathrm{PA}-\mathrm{aO}_{2}$ - alveolar-arterial oxygen gradient.

The results are given as mean $\pm \mathrm{SD}$. Means with different capital letters within each column and with different lower case letters within each row differed significantly. T0: time of measurements before pulmonary hypertension induction, T30: after 30 minutes of beginning continuous infusion of serotonin, T45 to T90: times of measurements taken 15 to 60 min after T30. BIS: value of bispectral index medium, HR: heart rate, systolic arterial pressure, DAP: diastolic arterial pressure, MAP: mean arterial pressure, SPAP: systolic pulmonary pressure, dPAP: diastolic pulmonary arterial pressure; mPAP: mean pulmonary arterial pressure, POAP: pulmonary arterial occlusion pressure, CI: cardiac index, TPRI: total peripheral resistance index, PVRI: pulmonary vascular resistance index.
At T45, in PG Raw was higher than in TG (Table 2). Intravenous anesthetics are known to cause bronchodilatation and to inhibit bronchoconstriction, but the effects of thiobarbiturates are more complex, as they may either contract or relax the airway smooth muscle, depending on the dose, since high concentrations produce bronchodilation (Gold, 1983). Thus, Raw was probably lower in the thiopental group due to this anesthetic dose having attenuated the serotonin-induced bronchoconstriction (Okamura and Denorough, 1980; Gross and Abel, 1985). Thiopental in similar concentrations to those used in human anesthesia $\left(250 \mu \mathrm{mol} \mathrm{L}{ }^{-1}\right)$ caused contracture of guinea pig tracheal smooth muscle, but, at concentrations greater than $400 \mu \mathrm{mol} \mathrm{L} \mathrm{L}^{-1}$, it caused relaxation. The reason why thiopental causes contraction at small concentrations and 
relaxation at large concentrations is not known (Okamura and Denorough, 1980).

The $\mathrm{PaO}_{2}$ depends on the $\mathrm{FiO}_{2}$, ventilation and the relation between ventilation and perfusion (V/Q match or mismatch). In anesthetized dogs the estimated $\mathrm{PaO}_{2}$ is 4 to 5 times the supplied $\mathrm{FiO}_{2}$ (\%) (Cortopassi et al., 2002), which coincides with this study's data (Table 2), which used a $\mathrm{FiO}_{2}=0.6$. Thus, these data are similar to those of Lopes et al. (2008a), who reported $\mathrm{PaO}_{2}$ values from 240 to $293 \mathrm{mmHg}$ in propofolanesthetized $\left(0.7 \quad \mathrm{mg} \quad \mathrm{kg}^{-1} \quad\right.$ minute $\left.^{-1}\right)$ dogs spontaneously breathing with a $\mathrm{FiO}_{2}=0.6$.

In $\mathrm{PG}, \mathrm{PaO}_{2}$ decreased and $\mathrm{PA}-\mathrm{aO}_{2}$ increased, from T60 and at T60, respectively. In TG, at T0, $\mathrm{PaO}_{2}$ was higher than at T30, T45, T60 and T90, while $\mathrm{PA}-\mathrm{aO}_{2}$ at $\mathrm{T} 0$ was lower than at $\mathrm{T} 90$ (Table 2). These events can be attributed to 5HT infusion, because this drug has vasoconstriction and bronchoconstriction effects, (Hashimoto et al., 2000; Hirota et al., 2002) allowing V/Q changes.

However, from $\mathrm{T} 30$ to $\mathrm{T} 90$, in $\mathrm{TG}$, the $\mathrm{PaO}_{2}$ means were higher than in PG (Table 2). As the $\mathrm{FiO}_{2}$ was the same for both groups, this difference occurred due to V/Q changes (Cortopassi et al., 2002) occurring in PG impairing gas exchange. This hypothesis can be confirmed by values of $\mathrm{PA}-\mathrm{aO}_{2}$ (Table 2 ), which provide a convenient and practical measure of the relative efficiency of gas exchange (McDonell and Kerr, 2007). In TG, PA-aO 2 was lower than in $\mathrm{PG}$, in which high values of this parameter occurred mainly due to V/Q and diffusion impairment (Levistzky, 2004). Thus, in $\mathrm{TG}$, the higher $\mathrm{PaO}_{2}$ values and lower $\mathrm{PA}-\mathrm{aO}_{2}$ means can be justified by hypotheses that the high concentration of thiopental may have attenuated the serotonin action, as proposed for PVRI and Raw.

For $\mathrm{PaCO}_{2}$, at $\mathrm{T} 0$, no difference between groups was registered. From T30, PG showed higher means than TG. In PG, from $\mathrm{T} 30, \mathrm{PaCO}_{2}$ values increased, while, in $\mathrm{TG}$, this parameter was stable (Table 2). It is possible to affirm that the changes in $\mathrm{PaCO}_{2}$ were related to gas exchange that was impaired by serotonin-induced vasoconstriction (Hashimoto et al., 2000) and bronchoconstriction (Hashimoto et al., 2000; Hirota et al., 2002). Thus, the dose of thiopental used may have attenuated the serotonin-induced pulmonary vasoconstriction (Gross e Abel 1985, Klockgether-Radke et al. 2000) and bronchoconstriction (Okamura and Denorough, 1980; Gross and Abel, 1985) promoted lower $\mathrm{PaCO}_{2}$ when compared with propofol.

For $\mathrm{pH}, \mathrm{BD}$, in $\mathrm{TG}$ means were higher than in PG from T45, while for $\mathrm{HCO}_{3}{ }^{-}$the values were lower in PG at T60 and T90. In both groups, $\mathrm{pH}$ and $\mathrm{BD}$ decreased from T30. In PG, bicarbonate decreased after $\mathrm{PH}$ induction (Table 2). The $\mathrm{pH}$ and $\mathrm{HCO}_{3}{ }^{-}$changes in $\mathrm{PG}$ could be explained by $\mathrm{PaCO}_{2}$ alterations, because acute increases in $\mathrm{PaCO}_{2}$ promote increase in intracellular $\mathrm{CO}_{2}$ levels, which shifts the reaction $\mathrm{CO}_{2}+\mathrm{H}_{2} \mathrm{O} \leftrightarrow$ $\mathrm{H}_{2} \mathrm{CO}_{3} \leftrightarrow \mathrm{HCO}_{3}^{-}+\mathrm{H}^{+}$to the right (Johnson and Morais, 2005). After pulmonary hypertension induction $\mathrm{PaCO}_{2}$ increased in both groups, thus, $\mathrm{H}^{+}$concentrations increased, too. In $\mathrm{TG}$, the lower $\mathrm{PaCO}_{2}$ promoted higher $\mathrm{pH}$ and $\mathrm{BD}$, which was obtained based on $\mathrm{pH}$ and $\mathrm{PaCO}_{2}$ (DiBartola, 2006)

By the concept presented above (Johnson and Morais, 2005) the increase of $\mathrm{HCO}_{3}^{-}$was expected in $\mathrm{PG}$, but the means decreased (Table 2 ). This event can be explained since the combination of respiratory acidosis with metabolic may occur in patients with acute and severe respiratory impairment. There is an addendum to the reductive effect of $\mathrm{pH}$, because the normal compensation for metabolic acidosis is impaired due to lung disease. Thus, bicarbonate is low, $\mathrm{PaCO}_{2}$ is normal or high and the resulting $\mathrm{pH}$ can be extremely low (Morais and Leisewitz, 2005).

According to Haskins (2004) the normal value for $\mathrm{P} \overline{\mathrm{V}} \mathrm{O}_{2}$ is between 40 and $50 \mathrm{~mm} \mathrm{Hg}$ in healthy dogs breathing room air. Means registered in both groups in this study were higher than $40 \mathrm{~mm} \mathrm{Hg}$ due to the use of $\mathrm{FiO}_{2}$ of 0.6. After $\mathrm{PH}$ induction $\mathrm{P} \overline{\mathrm{V}} \mathrm{O}_{2}$ increased in both groups and this can be attributed to $\mathrm{CI}$ increase after T30 (Morgan et al., 2005). A normal S $\overline{\mathrm{V}} \mathrm{O}_{2}$ is reported as $75 \%$, with a variation from $60 \%$ to $80 \%$ (Zaja, 2007). Thus, both groups had good tissue oxygenation. The $\mathrm{P} \overline{\mathrm{v}} \mathrm{CO}_{2}$ is usually 6 to 7 mmHg higher than the $\mathrm{PaCO}_{2}$ (Haskins, 2004), as observed in this study (Table 2). Thus, the $\mathrm{P} \overline{\mathrm{V}} \mathrm{CO}_{2}$ changes can be explained by the same statement used in $\mathrm{PaCO}_{2}$. 
During anesthesia recovery no complications (hypoxemia, arterial hypotension, bradycardia, hypothermia, signs of pain and others) were noticed for all animals in both groups. However, the recovery from thiopental was considerably longer than from propofol. The animals in the PG were standing about 3 hours after the end of the procedure. The dogs in the TG were standing about 50 hours after the infusion of thiopental had finished. During this period, the animals were under constant observation by one veterinarian. The dogs were kept in individual cages and positioned in lateral recumbency on a mattress. Every 3 hours the animal was rolled to its other side. The cages were maintained with low light and were noise free. Body temperature was controlled and maintained between 37 and $38.5^{\circ} \mathrm{C}$ and a warm $\mathrm{NaCl} 0.9 \%$ solution was administered. Three animals showed signs of euphoria, incoordination and paddling and when dogs awoke, polydipsia and polyphagia were observed.

In conclusion, in dogs, at the studied dose, thiopental anesthesia attenuated some of the cardiopulmonary changes resulting from serotonin-induced $\mathrm{PH}$, probably by attenuation of pulmonary vasoconstriction and bronchoconstriction. Despite better cardiopulmonary parameters, thiopental anesthesia had a prolonged recovery.

\section{ACKNOWLEDGEMENTS}

The authors would like to thank the Fundação de Amparo à Pesquisa do Estado de São Paulo FAPESP $\left(n^{\circ} 06 / 51483-8\right)$, for the financial support and scholarship.

\section{REFERENCES}

BONASSA, J. Princípios básicos dos ventiladores artificiais. In: CARVALHO, C.R.R. (Ed). Ventilação Mecânica Vol. II - Avançado. São Paulo: Atheneu, 2006. p.69-124.

BRANSON, K.R. Injectable and alternative anesthetic techniques. In: TRANQUILLI, W.J.; THURMON, J.C.; GRIMM, K. A. (Eds). Lumb \& Jones' Veterinary Anesthesia and Analgesia. 4th edn. Oxford: Blackwell Publishing, 2007. p.273-299.
CORTOPASSI, S.R.G.; FANTONI, D.T.; KITAHARA, F.R. et al. Complicações da anestesia. In: FANTONI, D.T.; CORTOPASSI, S.R.G. (Eds). Anestesia em cães e gatos. São Paulo: Roca, 2002. p.347-361.

DIBARTOLA, S.P. Introduction to acid-base disorders. In: DIBARTOLA, S.P. Fluid, electrolyte and acid-base disorders in small animal practice. 3rd. edn. Philadelphia: Saunders Elsevier, 2005. p.229-250.

ELLISON, L.T.; HALL, D.P.; YEH, T. et al. Physiological alterations in increased pulmonary blood flow with and without pulmonary hypertension. J. Appl. Physiol., v.16, p.305-308, 1961.

FISCHER, L.G.; AKEN, H.V.; BÜRKLE, H. Management of pulmonary hypertension: physiological and pharmacological considerations for anesthesiologists. Anesth. Analg., v.96, p.1603-1616, 2003.

FRISHMAN, W.H.; GREWALL, P. Serotonin and the heart. Ann. Med., v.32, p.195-209, 2000.

GOLD, M.I. Bronchospasm and asthma in the anesthetized patient. ASA Annual Refresher Course Lectures, v.201, p.242-248, 1983.

GROSS, C.E.; ABEL, P.W. Contraction and relaxation of rabbit basilar artery by thiopental. Neurosurgery, v.17, p.433-435, 1985.

HASHIBA, E.; HIROTA, K.; YOSHIOKA, H. et al. Milrinone attenuates serotonin-induced pulmonary hypertension and bronchoconstriction in dogs. Anesth. Analg., v.90, p.790-794, 2000.

HASHIMOTO, Y.; HIROTA, K.; YOSHIOKA, H. et al. A comparison of the spasmolytic effects of olprinone and aminophylline on serotonin-induced pulmonary hypertension and bronchoconstriction with or without (beta)blockade in dogs. Anesth. Analg., v.91, p.13451350, 2000.

HASKINS, S.C. Interpretation of blood gas measurements. In: KING, L.G. (Ed). Textbook of respiratory disease in dogs and cats. Philadelphia: Saunders, 2004. p.181-192.

HIROTA, K.; YOSHIOKA, H.; KABARA, S. et al. Spasmolytic effects of colforsin daropate on serotonin-induced pulmonary hypertension and bronchoconstriction in dogs. Acta Anaesthesiol. Scand., v.46, p.297-302, 2002. 
JOHNSON, L. Diagnosis of pulmonary hypertension. Clin. Tech. Small. Anim. Pract., v.14, p.231-236, 1999.

JOHNSON, L.; BOON, J.; ORTON, E.C. Clinical characteristics of 53 dogs with Doppler-derived evidence of pulmonary hypertension:1992-1996. J. Vet. Intern. Med., v.13, p.440-447, 1999.

JOHNSON, R.A.; MORAIS, H.A. Respiratory acid-base disorders. In: DiBARTOLA, S.P. (Ed). Fluid, electrolyte and acid-base disorders in small animal practice. 3rd edn. Philadelphia: Saunders Elsevier, 2005. p.283-296.

KELLUM， H.B.; STEPIEN， R.L. Sildenafil citrate therapy in 22 dogs with pulmonary hypertension. J. Vet. Intern. Med., v.21, p.12581264, 2007.

KLOCKGETHER-RADKE，A.P.; FRERICHS, A.; KETTLER, D. et al. Propofol and thiopental attenuate the contractile response to vasoconstrictors in human and porcine coronary artery segments. Eur. J. Anaesth., v.17, p.485490, 2000.

LEVISTZKY, M.G. Relações ventilação perfusão. In: LEVISTZKY, M.G. (Ed). Fisiologia pulmonar. São Paulo: Manole, 2004. p.113-129.

LOPES, P.C.F.; NUNES, N.; NISHIMORI, C.T. et al. Efeitos de diferentes frações inspiradas de oxigênio no índice biespectral em cães submetidos à infusão contínua de propofol. Arq. Bras. Med. Vet. Zootec., v.60, p. 359-366, 2008 a.

LOPES, P.C.F.; NUNES, N.; PAULA, D.P. et al. Bispectral index in dogs at three intravenous infusion rates of propofol. Vet. Anesth. Analg., v.35, p.228-231, 2008b.

MCDONELL, W.; KERR, C.L. Respiratory System. In: TRANQUILLI, W.J.; THURMON, J.C.; GRIMM, K.A. (Eds). Lumb \& Jones Veterinary Anesthesia and Analgesia. 4th edn. Oxford: Blackwell Publishing, 2007. p.117-151.
MORAIS, H.A.; LEISEWITZ, A.L. Mixed acidbase disorders. In: DIBARTOLA, S.P. Fluid, electrolyte and acid-base disorders in small animal practice. 3rd. edn. Philadelphia: Saunders Elsevier, 2005. p.296-309.

MORGAN JR, G.E.; MIKHAIL, M.S.; MURRAY, M.J. Respiratory physiology: The effects of anesthesia. In: MORGAN JR, G.E.; MIKHAIL, M.S.; MURRAY, M.J.(Eds). Clinical anestesiology. 4th edn. New York: Lange Medical books/McGraw-Hill, 2005. p.537-570.

NOZIK-GRYCK, E.; McMAHON， T.J.; HUANG, Y.C. et al. Pulmonary vasoconstriction by serotonin is inhibited by S-nitrosoglutathione. Am. J. Physiol. Lung Cell Mol. Physiol., v.282, p.L1057-L1065, 2002.

OKAMURA, F.; DENBOROUGH, M.A. Effects of anaesthetics on guinea pig tracheal smooth muscle. Br. J. Anaesth., v.52, p.199-204, 1980.

SAWYER, D.C. Injectable anesthetics. Appl. Anim. Behav. Sci., v.59, p.171-181, 1998.

VUYK, J.; MERTENS, M. Bispectral Index Monitoring and Intravenous Anaesthesia. In: VUYK, J.; SCHRAAG, S. (Eds). Advances in Modelling and Clinical Application of Intravenous Anaesthesia. New York: Springer, 2003. p.95-104.

YOSHIOKA, H.; HIROTA, K.; SATO, T. et al. Spasmolytic effect of magnesium sulfate on serotonin-induced pulmonary hypertension and bronchoconstriction in dogs. Acta Anaesthesiol. Sacand., v.45, p.435-440, 2001.

ZAJA, J. Venous oximetry. Signa Vitae, v.2, p.610, 2007. 